\title{
Implementation of tahfizhul Qur'an learning at PPTQ Griya Qur'an 3 Putri Klaten
}

\author{
Hastini $^{*}{ }^{*}$ https://orcid.org/0000-0002-1990-3897 \\ Maslamah $^{1}{ }^{\circ}$ https://orcid.org/0000-0002-2818-5612
}

${ }^{1}$ UIN Raden Mas Said Surakarta, Indonesia

\begin{abstract}
The management of the PPTQ Griya Qur'an 3 Putri Klaten has been designed with modern management carried out by ustadzah (female teacher) and mudir as the center. The number of students was 80 , and had graduated 2 generations of around 40 students. The purpose of this research is to describe the teaching and learning process at Tahfidz Qur'an. This research used a qualitative descriptive method, conducted at the PPTQ Griya Qur'an 3 Putri Klaten in January-July 2020. The research subjects were ustadzah. The informants were the boarding school leaders and the students. Data collection was carried out by observation technique, interviews, and documents. The validity of the data used source and data triangulation techniques. Meanwhile, the analysis technique used interactive data analysis encompassing data collection, data reduction, then presentation and conclusion. Based on the research, there are three stages of learning tahfizh; the first is the preliminary stage (pre-instructional), the second is the core stage (instructional) containing the implementation of muraja'ah and ziyadah students, then the teacher listens/justifies the students' readings, and the third is assessment stage. Evaluations include daily evaluations and level-up evaluations. Daily evaluation is done by the verse memorized every day, while the evaluation of the time level can be carried out at any time when the students are ready to memorize 30 juz'.
\end{abstract}

\author{
ARTICLE INFO \\ Keywords: \\ boarding school; \\ management; tahfidz Qur'an; \\ teaching and learning
}

\section{Article History:}

Received: 23 February 2021

Revised: 21 August 2021

Accepted: 14 November 2021

Published: 30 December 2021

\section{How to Cite in APA Style:}

Hastini \& Maslamah. (2021).

Implementation of tahfizhul Qur'an learning at PPTQ Griya Qur'an 3 Putri Klaten. Journal of Educational Management and Instruction, 1(2), 111-118.

\section{Introduction}

Memorizing the Qur'an is an easy thing but not much interest. However, in PPTQ Griya Qur'an 3 Putri Klaten, it is able to realize santri (students) to memorize the Qur'an well. Besides, santri reaches a proud achievement in SMA Muhammadiyah 1 Klaten. Since the beginning of its establishment, the management of the boarding school has been designed with modern management by asatidzah and mudir as its center. In the morning, students attend the teaching-learning process at SMA Muhammadiyah 1 Klaten. Their achievements are not inferior to other students despite having the task of memorizing the Qur'an, This can be seen from the results of the students' report scores.

Salma Karima, one of the students of class XII ID at SMA Muhammadiyah 1 Klaten, got great scores in the academic year of 2020. She also achieved the first rank in her class. Moreover, Salma Karima also achieved memorization of 30 juz'/khatam (finished).

The students tried to divide the time to be able to achieve school achievement even though boarding school activities were congested. This is proven by students who attend SMA Muhammadiyah 1 Klaten have good grades compared with students who do not study at PPTQ Griya Qur'an 3. Students of PPTQ Griya Qur'an 3 Putri Klaten always get first ranked for every grades at SMA Muhammadiyah 1 Klaten. So, this research aims to 
describe the implementation of Tahfizhul Qur'an learning in the PPTQ Griya Qur'an 3 Putri Klaten. Because PPTQ Griya Qur'an 3 Putri Klaten can generate students who can memorize the Qur'an thoroughly and according to the learning target.

\section{Theoretical Studies}

\section{Learning}

According to Hardini (2012), learning is closely related to the understanding of learning and teaching. In the Great Dictionary of The Indonesian Language "Learning is, processes, ways, deeds, making people or living things learn (Zahari, 2017). According to Pane \& Dasopang (2017), learning is a planned activity that condition or stimulate a person to learn well, so that this learning activity boils down to two main activities, namely how people perform behavior change actions through learning activities and how people perform the act of conveying science through teaching activities. Meanwhile, according to Daryanto \& Rahardjo (2012), the management of teaching and learning activities is a thorough and learning process starting from planning, implementation to the evaluation of learning including evaluation of the program to achieve educational objectives as determined.

In the implementation of the management of teaching and learning activities, it must understand the principles of learning first, so that on that basis will get optimal management results (Sanjaya, 2009). According to Hamdani (2010), the principles of learning are learning readiness, motivational attention, student activity, experiencing for themselves, repetition, challenging subject matter, reverse and strengthening, individual differences.

As a system of course teaching and learning activities contain several components, according to Sagala (2011), which is the goal of prison, learners, educators, lesson materials, learning methods, tools, learning resources, and evaluation. Meanwhile, according to Hamdani (2010) learning components include objectives, learning subjects, subject matter, learning strategies, learning media, and support. In the management of the learning program, several steps or stages must be undertaken by a teacher. According to Majid (2014) in general, there are three main stages of learning, namely the initial stage (pre-instructional), the teaching stage (instructional), and the assessment or follow-up stage. Meanwhile, Suharsimi Arikunto (1997) argues that the learning stages include: Preparation or Planning Stage, Implementation Stage and Assessment Stage (Evaluation).

\section{Tahfizhul Qur'an}

The word tahfiz is a masdar form of haffaza, the origin of the word hafiza-yahfazu which means "memorization" (N. Hidayah, 2016). The Qur'an is the word of Allah Swt and we have been sent down by the spirit, revealed to us by the spirit of Allah Swt of the worlds (Rohmatillah \& Shaleh, 2018). The term Tahfizhul Qur'an is a combination of tahfidz and Qur'an. Tahfizhul Qur'an means to keep, maintain or memorize. Meanwhile, etymologically (the origin of the word) the Qur'an comes from the Arabic word qaraa (قرا) which means to read, while al-Farra' says that the word Qur'an comes from the word qara>in) (قران the plural form qari>nah (قرينه with the meaning of hooks because the part of the Qur'an is related to the other part. Al-Ash'ari identifies the etymology of the Qur'an derived from the word qarn (قرن) which means a combination of various verses, letters, and so on (Ghautsani, Yahya bin "Abdurrazaq, 2010). "Hafalan" is derived from the root word "hafal" which means to have entered into the memory or can say something out of your head without other books or notes. So memorization is trying to penetrate the mind to always remember without books or notes (Ii, n.d.). Reading the Qur'an is the best dhikr, therefore it is highly recommended to every Muslim to read the Qur'an every day so that the heart always remembers Allah. According to Al-Makhtum \& Iryadi (2018), 
some of the virtues of memorizing the Qur'an are: the inherited knowledge, elevated, intercession on the Day of Resurrection, crowned glory, and kept away from hell.

The Qur'an is studied not only the composition of the editor and the selection of vocabulary, but also its express content implied even to the impression it causes. The Qur'an is an orderly book of its reading procedures, which are shortened, extended, thickened, or refined, where the place is forbidden or permissible, or must begin and stop. Jumhur scholars argue that reading the Qur'an is more important than reading rosary, tahlil, or other dhikr. Reading the Qur'an is the best remembrance, therefore it is highly recommended to every Muslim to read the Qur'an every day so that the heart always remembers Allah (Sa'dulloh, 2008). Memorizing the Qur'an is a form of interaction between Muslims with the Qur'an that has been going down in descent since the Qur'an first came down to the Prophet Muhammad SAW until now and the future (A. Hidayah, 2018). The Qur'an can give intercession to its owner and can put him in heaven (M. Taqiyul Islam, 1998). Memorizing the Qur'an is fardhu kifayah. This means that the person who memorizes the Qur'an should not be less than the number of mutawatirs so there will be no possibility of forgery and alteration of the holy verses of the Qur'an. If this obligation has been fulfilled by several people (who reach the level of mutawatir) then fall the obligation from the others. On the contrary, if this obligation is not fulfilled then all Muslims will bear their sins (Sa'dulloh, 2008).

\section{Method of Memorizing the Qur'an}

Memorizing the Qur'an is not a task and easy thing, meaning it is not as easy as palm. One of the efforts most importantly noted in the construction of tahfizh the Qur'an is a method (Tahfidz et al., 2016). There are several methods of memorizing the Qur'an. Among the methods of memorization according to Sa'dullah are as follows: 1) Bi-nadzar method, which is to read carefully the verses of the Qur'an that will be memorized by looking at the mushaf repeatedly. 2) Tahfidz method, which is to memorize little by little verses of the Qur'an that have been read repeatedly bi-nadzar. 3) Talaqqi method, which is depositing newly memorized memorization to a teacher. 4) Takrir method, which is to repeat the memorization that has been memorized by the teacher. 5) Tasmi method, which is to listen to memorization to others, both individually and to worshippers (Risa, Ahmad, Arifi, 2017). Method of reading the verse to be memorized by reading verses of the Qur'an that are memorized repeatedly, then only memorize it. This method is applied by the students of al-Utrujah Jakarta that can complete the memorization of 10 juz' within 10 months. Thus, one month they managed to memorize 1 juz' (Masyhud, 2016).

\section{Method}

\section{Research context and participants}

The approach of this research used a qualitative descriptive method. Research subjects were the main actors in this study, which can provide data on variables studied (Suryana, 2015). The subject of the research was ustadzah. According to Moleong (2013) informants are people who are used to provide information about the situation and conditions of the research background. The informant was the leader of the boarding school, and the students of PPTQ Griya Qur'an 3 Putri Klaten. Data collection was done by observation method, interview, and document. To find out the validity of data was used triangulation techniques of sources and data, while analysis techniques applied interactive data analysis encompassing data collection, data reduction, then a presentation and concluding.

Table 1. List and position of ustadz/ustadzah at PPTQ Griya Qur'an 3 Putri Klaten

\begin{tabular}{llll}
\hline No & Name & G & Position \\
\hline 1 & Makmur Santosa S.Pd.I & L & Ustadz (kyai) \\
\hline
\end{tabular}




\begin{tabular}{llll}
\hline No & Name & G & Position \\
\hline 2 & Kunti Maftuhah & $\mathrm{P}$ & Ustadzah \\
3 & Khusnul Khotimah & $\mathrm{P}$ & Ustadzah \\
4 & Ulyatuz Zahro & $\mathrm{P}$ & Ustadzah \\
5 & Roifatur Rosyidah & $\mathrm{P}$ & Ustadzah \\
6 & Ratna Jauhara El Rohman S.Pd & $\mathrm{P}$ & Ustadzah \\
7 & Siti Khoiriyah S.Pd.I & $\mathrm{P}$ & Ustadzah \\
\hline
\end{tabular}

Table 2. Class of students at PPTQ Griya Qur'an 3 Putri Klaten

\begin{tabular}{lll}
\hline No & Class & Total \\
\hline 1 & Class X HS & 27 \\
2 & Class XI HS & 27 \\
3 & Class XII HS & 26 \\
\hline & & Total \\
\hline
\end{tabular}

\section{Instruments and data collection}

Descriptive qualitative research was a method of examining the status of a group of humans, an object to make descriptive also a research procedure that produces descriptive data in the form of written and oral words from people and observable behavior (Moleong, 2007). Meanwhile, according to Arifin (2014) qualitative research is research to answer problems that require deep understanding in the context of the time and situation concerned. The research aims to describe in detail the implementation of learning tahfidzul Qur'an in PPTQ Griya Qur'an 3 Putri Klaten. According to Bungin (2011) explains that when the observer is following the activities that are being observed, then he/she should pay attention to the following: What should be observed, how to do the recording. There are three kinds of observations, namely (a) participation observation (b) frank or disguised observation (c) unstructured observation (Sugiyono, 2017) with this method researchers can observe closely i.e. observe directly the implementation of learning tahfidzul Qur'an when in boarding school.

The interview was submitted to ustadzah, students, and administrators of PPTQ Griya Qur'an 3 Putri Klaten to obtain information related to the implementation of learning tahfidzul Qur'an in PPTQ Griya Qur'an 3 Putri Klaten so that through the interview method will get primary data. This data collection was an interview activity to obtain data and information about the history of the start of tahfidzul Qur'an activities, the number of students, methods used, the learning process, and evaluation in the learning process. This documentation method is used to obtain documented information with valid data of teaching schedule, presence, learning materials, learning results report, control book, and students, organizational structure, learning implementation process, facilities, and infrastructure used in learning and evaluation in PPTQ Griya Qur'an 3 Putri Klaten.

\section{Data analysis}

The data analysis in this study applied qualitative descriptive data analysis techniques of interactive models (Sumardjoko, 2015). In analyzing the data, researchers used a sequential phasing method consisting of four simultaneous flow of activities, namely data collection, data reduction, data model (presentation), and conclusion (Moleong, 2013). The first step to take was data collection. After the data collection was complete, there was a reduction of data which was a form of analysis that sharpens, classifies, directs, discards unnecessary, and coordinates the data in such a way that conclusions can be drawn and verified. Furthermore, the reduced data will be presented in the form of narration. So that it can conclude from the data that has been presented, then at the stage of concluding each formulation. So the conclusion of the data is intended 
for determination in the form of final data and the whole process of analysis stages so that the whole problem of the implementation of learning tahfidzul Qur' an in PPTQ Griya Qur'an 3 Putri Klaten can be answered by the data and problems.

\section{Results}

Based on the data obtained through interviews, observations, and documentation, the analysis is obtained as follows. PPTQ Griya Qur'an 3 Putri Klaten has several ways in improving the quality of learning tahfidzul Qur'an namely to learn tahfidzul Qur'an, determination of materials, determination of allocation of lesson hours, implementation of learning, and evaluation of learning. So in the learning of tahfidzul Qur'an, it can be seen from the method because the method is very influential in the learning process tahfidzul Qur'an. One of the students is Hana Rosyidah; every day she can deposit her memorization at least one verse or more depending on the short length of the verse. The targeted memorization of the school is 5 juz at the beginning of the Hana memorization learning year less than one juz and the number of memorizations is now 5 juz, which means there is an increase in the number of memorizations following the target set in the school. So every student in PPTQ Griya Qur'an 3 Putra and PPTQ Griya Qur'an 3 Putri Klaten has their way of memorizing. With the success of the method that has been done pesantren, the number of students who have succeeded also increased from year to year, so that public trust is increasing also with the tahfidz program in pesantren.

The implementation of Qur'an memorization learning in PPTQ Griya Qur'an 3 Putri Klaten runs seriously but casually. The learning is done in a hall of boarding school with a comfortable and cool nuance without chairs and benches but without chairs. The implementation of Tahfizhul Qur'an Learning in this section will be described the data of research and analysis obtained from PPTQ Griya Qur'an 3 Putri Klaten concerning the preparation of learning carried out by the Ustadzah. To find out the preparation of learning conducted by Ustadzah interviewed Roifatur Rosyidah as ustadzah tahfidzhul Qur'an. He explained that before the learning is carried out first set the objectives of learning, learning materials, learning media, and learning methods. (Interview with Roifatur Rosyidah).

Based on the interview from ustadzah Roifatur Rosyidah, she states that the purposes of learning with the expected target as a result of the activities of learning tahfizhul Qur'an are as follows; (1) To make Santri memorize the Qur'an at least 5 juz starting from juz 26 to 30, after that starting from juz 1 until completion, (2) To print generations of Qur'ani (a person who memorizes the Qur'an / hafidz and Islamic character) who has an intellectual ability with excellent achievements in various disciplines, (3) To encourage, nurture and guide the students to favor memorizing the Qur'an and practicing it daily.

From ustadzah's explanation above, she argues that the purpose of learning tahfizhul Qur'an in PPTQ Griya Qur'an 3 Putri Klaten is the students can memorize the Qur'an correctly. The ultimate goal in the implementation of learning in addition to memorization, learners also learn to be able to understand the meaning of the memorized verse. Ustadz Makmur Santosa also explains that the average santri memorization target can reach the target and some of them exceed up to juz 30.

Memorization material of tahfizhul Qur'an in boarding school of PPTQ Griya Qur'an 3 Putri Klaten has the target of memorization for each santri at least 5 juz. This starts from juz 26-30, then just starting from juz 1 . But there are also santri who can memorize 10 juz, for children who already have memorization is more targeted to be able to khatam gradually; surah by surah. For santri who has never had any memorization at all began memorizing from juz 30-26. Although tahfidz learning has memorization materials at every level, tahfidz itself does not impose santri to deposit their memorization every important time they must always with the Qur'an at least 
repeat the memorization that has been memorized santri. (Interview with ustadzah Khusnul).

The implementation of learning activities is an effort made by educators to realize the design that has been prepared in the learning plan. Therefore, the implementation of learning activities shows the implementation of methods and strategies for teaching and learning activities. When the author observes the learning process of tahfizhul Qur'an at PPTQ Griya Qur'an 3 Putri Klaten, in the outline the steps of tahfizhul Qur'an learning activities in PPTQ Griya Qur'an 3 Putri Klaten are as follows. Steps of Tahfizhul Qur'an learning activities. Tahfizhul Qur'an learning process at PPTQ Griya Qur'an 3 Putri Klaten on Thursday 2 February 2020, including the first activity, is preliminary activities, in the preliminary activities, the students performed ashar prayer together in the hall of the boarding school before carrying out a learning process. And then the students read asmaul husna with the ustadzah. Activities on the first day of learning tahfidzul Qur'an, namely Siti Khoiriyah in the learning process carried out the opening activities. The learning begins with greetings by ustazah Siti, "Assalamu"alaikum Wr. Wb. and she smiles to the students. Then she starts reading prayers and the students immediately followed at the same time. Then it is followed with reading al-Fatihah recited by her and all the students. Only after that, all the students and her pray together

Then, the second is the main activities, in this learning process ustadzah Siti Khoiriyah conducts core activities with students actively. Before starting the core activities ustadzah Siti sees the students who are neat and organized. So she continued the learning by telling all the students to prepare the Qur'an which they used to use in the process of learning tahfidzul Qur'an and the present material is muroja'ah, without being told by one of the learners directly forward to ustadzah Siti to repeat the memorization yesterday. Hafsah Kin, one of the santri, at that time, she memorizes Surah Al-Baqarah repeating verses 57-59, and she memorizes verses 53-77. In this lesson, other students listened and prepared memorization with calm and circumcision waiting for their turn to face her.

The last is closing activities, in this stage ustadzah Siti explains the wrong memorization and justified the memorization that is still not correct by repeating the learned. In this stage, the teacher tells the students memorizing the Qur'an that they are still not fluent. Lastly, ustadzah Siti closes the learning by reading Shodaqallahul Adzim and praying together. Then she gives the closing greeting "Wassalamu"alaikum Wr. Wb. and answered Wa"alaikumsalam Wr.Wb with enthusiasm by the learners.

\section{Discussion}

Based on the research findings, it can be concluded that the method used by students to memorize is memorizing sheet by sheet. For the tahfidz program, it applies the method of the live report (per person), for example, student listens to memorize in front of ustadzah, and muraja'ah (together) that they read the surah or verse ordered by ustadzah.

In learning this method, it is carried out where the students deposit the memorization of the Qur'an in turn, then the teacher listens one by one. In this method, before the students continue their memorization, the verses that have been successfully memorized are checked again in the meeting. According to the researcher, this talaqqi method is appropriate, because it is in accordance with the theory. In memorizing the Qur'an, a mature method is needed so that it can run properly and well. For this reason, this method is a condition that must be met so that the memorization carried out can produce satisfactory results. So from the results of observations and also checking the truth of information through interviews regarding the steps taken in learning at PPTQ 3 Putri in accordance with the results of research that has been carried out by Uswatun Khasanah (2020) regarding the implementation of the talaqqi method in learning tahfidzul Qur'an which describes the learning process using that method. 
The sorogan method allows students to memorize directly using the Mushaf. When it is time to deposit the memorization, the mushaf is just closed. In the memorization process, it emphasizes the readiness of students and is not appointed or randomly selected by the ustadzah to deposit memorization. The results of this study are in line with research conducted by Rahmi Dwi Nurlia on the effectiveness of the sorogan method at the Al Hidayah Islamic boarding school which describes the learning steps using the sorogan method.

The muraja'ah method is carried out to maintain the memorization of the students. The repetition is carried out consistently with the ustad (Khasanah)zah at least three repetitions. In addition to memorizing, maintaining memorization is also very necessary in learning tahfidzul Qur'an. This method can be combined with other methods. This is in line with research conducted by Rofiqotul Munifah (2017) on the effectiveness of the muraja'ah method in memorizing the Qur'an. According to the researcher, the muraja'ah that was done by checking with his friends was very helpful in the smooth memorization of the students, but regarding the makhraj and tajwid if it was checked by his own friends, it did not necessarily help the students' memorization fluency.

In the process of depositing memorization using the verse by verse method, students are allowed to memorize directly from the mushaf when facing the ustadzah. Then after that it will be continued for the next verse in the same way. This method is an interlude to the memorization method at the women's boarding school to increase memorization based on the readiness of the students. According to Sa'dullah (2008) in his book, the application of this method must be able to continue his memorization from the previous verse so that there is no breaking of memorization. In using this method it looks simple but needs to be done carefully and istiqomah in memorizing so that memorization can be continued.

Evaluation is done to know the level of memorization of the students to the verses and surah that have been memorized. Evaluation daily report is done at the end of tahfidz lesson hours. For its implementation usually ustadzah tell forward students who have memorized or can also by calling one by one by bringing a monitoring book. After that, ustadzah gave a note of assessment in the monitoring book tahfidz. This report evaluation is intended for students who are always routine and diligent in memorizing so that students are expected to be able to achieve the targets. The implementation of learning activities is carried out by ustadz and ustadzah to realize the curriculum that has been prepared in the learning plan to achieve the targeted results.

\section{Conclusion}

Based on the discussion and analysis of data in the previous chapters, it can be concluded that before carrying out the learning PPTQ Griya Qur'an 3 Putri Klaten set the steps with learning planning, implementation of learning, and evaluating learning. Learning strategies tahfidzul Qur'an has an impact on increasing the success of santri in memorizing the Qur'an, learning strategies are also evaluated. The learning process of tahfidzul Qur'an PPTQ Griya Qur'an 3 Putri Klaten was carried out by using various strategies tailored to the ability to memorize children and the condition of children who have not fluently read the Qur'an. The success of learning strategies that have been carried out the boarding, and the use of learning in PPTQ Griya Qur'an 3 Putri Klaten, the number of students who have succeeded have increased from year to year so that public confidence is increasing also with the tahfidz program in pesantren.

\section{Acknowledgment}

Acknowledgements and thanks go to all ustadz/ustadzah and students of PPTQ Griya Qur'an 3 Putri Klaten who were supported and willing to be the participants in this research. 


\section{References}

Makhtum, S., \& Iryadi, Y. (2018). Karantina Hafal Al-Qur'an Sebulan. CV. Alam Pena. Arifin, Z. (2014). Evaluasi Pembelajaran. PT. Remaja Rosda Karya.

Bungin, B. (2011). Penelitian Kualitatif: Komunikasi, Ekonomi, Kebijakan Publik, dan Ilmu Sosial Lainnya. Kencana.

Daryanto, \& Rahardjo, M. (2012). Model Pembelajaran Inovatif. Gava Media.

Ghautsani, Yahya bin 'Abdurrazaq, A. (2010). Cara Mudah dan Cepat Menghafal al-Qur'an terj. Zulfan. Pustaka Imam Asy-Syafi'i.

Hamdani. (2010). Strategi Belajar Mengajar. Pustaka Setia.

Hardini, I. dan D. P. (2012). Strategi Pembelajaran Terpadu. Familia.

Hidayah, A. (2018). Metode Tahfidz Al-Qur'an Untuk Anak Usia Dini (Kajian Atas Buku Rahasia Sukses 3 Hafizh Quran Cilik Mengguncang Dunia). Jurnal Studi Ilmu-Ilmu Al-Qur'an Dan Hadis, 18(1), 51. https://doi.org/10.14421/qh.2017.1801-04

Hidayah, N. (2016). Strategi Pembelajaran Tahfidz Al-Qur'an di Lembaga Pendidikan. Ta'allum: Jurnal Pendidikan Islam, 4(1), 63-81. https://doi.org/10.21274/taalum.2016.4.1.63-81

M. Taqiyul Islam, Q. (1998). Cara Mudah Menghafal Al-Qur'an. Gema Insani Press.

Majid, A. (2014). Strategi Pembelajaran. PT. Remaja Rosda Karya.

Masyhud, F. dan I. H. R. (2016). Rahasia Sukses 3 Hafizh Qur'an Cilik Mengguncang Dunia. Zikrul Hakim.

Moleong, L. J. (2007). Metodologi Penelitian Kualitatif. PT. Remaja Rosda Karya.

Moleong, L. J. (2013). Metodologi Penelitian Kualitatif. PT. Remaja Rosdakarya.

Pane, A., \& Dasopang, M. D. (2017). Belajar dan Pembelajaran. Fitrah:Jurnal Kajian IlmuIlmu Keislaman, 3(2), 353.

Risa, Ahmad. Arifi, A. U. (2017). Aktualisasi Pendidikan Al- Habit-Forming pada Anak Usia Dini di TK Al-Kautsar Durisawo Ponorogo. Al-Athfal: Jurnal Pendidikan Anak, 3(1), 65-81.

Rohmatillah, S., \& Shaleh, M. (2018). Manajemen Kurikulum Program Tahfidz Al-Qur'an di Pondok Pesantren Salafiyah Syafi'iyah Al-Azhar Mojosari Situbondo. Jurnal Pendidikan Islam Indonesia, 3(1), 107-267. https://doi.org/10.35316/jpii.v3i1.91

Sa'dulloh, S. (2008). 9 Cara Praktis Menghafal Al-Qur'an. Gema Insani Press.

Sagala, S. (2011). Konsep Dan Makna Pembelajaran. PT. Remaja Rosda Karya.

Sanjaya, W. (2009). Strategi Pembelajaran Berorientasi Standar Proses Pendidikan. Kencana Prenada Media Group.

Sugiyono. (2017). Metode Penelitian Pendidikan. Alfabeta.

Sumardjoko, B. (2015). Diktat Perkuliahan Metodologi Penelitian Kualitatif. Universitas Muhammadiyah Surakarta.

Suryana, Y. (2015). Metode Penelitian Manajemen Pendidikan. CV. Pustaka Setia.

Tahfidz, M., Di, A. A. N., \& Pesantren, P. (2016). Ali Akbar dan Hidayatullah Ismail. Jurnal Ushuluddin, 24(1), 91-102.

Zahari, I. (2017). Pembelajaran Tahfizh Al Qur'an Pesantren Nurul Huda Mergosono Malang. Ta'allum: Jurnal Pendidikan Islam, 5(1), 53-66. https://doi.org/10.21274/taalum.2017.5.1.53-66 